\title{
Age and growth of thread herring Opisthonema libertate, in the southern Gulf of California
}

\author{
Jorge Payan-Alejo ${ }^{1}$, Mercedes L. Jacob-Cervantes ${ }^{2}$ \& Guillermo Rodríguez-Domínguez ${ }^{1}$ \\ ${ }^{1}$ Facultad de Ciencias del Mar, Universidad Autónoma de Sinaloa, Mazatlán, Sinaloa, México \\ ${ }^{2}$ Centro Regional de Investigación Pesquera, Instituto Nacional de Pesca, Mazatlán, Sinaloa, México \\ Corresponding author: Guillermo Rodríguez-Domínguez (guirodom@uas.edu.mx)
}

\begin{abstract}
To fit a growth model to Opisthonema libertate, the most common thread herring in a small pelagic fishery in the southern Gulf of California, size data of commercial landings and age were generated from sagittal otoliths assessed during three different years, 2005, 2008 and 2015, representing Neutral, La Niña and El Niño environmental conditions, respectively. A multimodel select approach on five special submodels of generalized Schnute model, including one, equivalent to the Von Bertalanffy model, were used. A total of 573 otoliths were analyzed; 219 from Neutral, 149 from El Niño and 205 from The Niña events. An opaque zone of otoliths formed in winter-spring when chlorophyll $a(\mathrm{Chl}-a)$ concentrations were at a maximum. However, a hyaline zone of otoliths formed during the summer of the reproductive period. Schnute submodel 1 was the best model selected in all three environmental conditions, but submodel 3 was the best on pooled data. Length of thread herring aged 0.5 years old in the El Niño year was lower than other environmental-years analyzed. A possible compensatory effect on growth with age was observed in the data because environmental conditions affected the growth of 0.5-year-old thread herring, as was evident in size variance in this age group under all three conditions, but variance decreased in the older age groups. Thus, a multimodel average of Schnute submodels 1 and 3 could be used to describe the growth of $O$. libertate in the southern Gulf of California.
\end{abstract}

Keywords: Opisthonema liberate; growth; compensatory effect; multi-model selection; Gulf of California

\section{INTRODUCTION}

A small pelagic fishery of three thread herring species, Opisthonema libertate (Günther, 1867), O. bulleri (Regan, 1904), and O. medirastre (Berry \& Barrett, 1963), and one anchovy, Cetengraulis mysticetus (Günther, 1867), operates in the southern Gulf of California, and O. libertate comprises 50 to $75 \%$ of landings (Ruiz \& Lyle, 1992; Jacob-Cervantes, 2010).

The interannual variability on abundance and distribution of commercial landings of small pelagic fishes in the Gulf of California (GC) have been associated with spatial and seasonal chlorophyll- $a$ concentration (Chl-a), sea surface temperature gradients and El Niño and La Niña events (Lluch-Belda et al., 1986; Ruiz \& Lyle, 1992; Cisneros-Mata et al., 1996; Lanz et al., 2009).

During El Niño events, weakening northwesterly prevailing winds decrease upwellings and the concentration of Chl- $a$. Conversely, in La Niña events, a strengthening northwesterly winds increase upwellings and thermal fronts in the oriental coast of GC (Durazo et al., 2005; Espinosa-Carreón \& Valdez-Holguín, 2007; Escalante et al., 2013). This physical variation in GC influences primary productivity and exert downstream impacts on higher trophic levels. As the individual growth rate depends on food availability and stock size, the growth rate likely varies with the environment.

Assessing the environmental effect on the individual growth of a wild marine organism is difficult, because of, individuals in each age has been exposed to different environmental conditions (Neutral, La Niña and El Niño) throughout their lives, as they birthed on different years. However, as the growth of these species is asymptotic (Gallardo-Cabello et al., 1993; Carmona \& Alexandres, 1994; Ruiz-Domínguez \& QuiñonezVelázquez, 2018), the environmental effect on the growth rate will be more evident in the first year of life, during faster growth. Therefore, if we contrast the

Corresponding editor: Yassir Torres 
growth of fish collected in years with different environmental conditions, the most substantial difference will be seen during the first year of life.

The most studied and commonly applied model among all the length-age models is the Von Bertalanffy growth model (VBGM) (Von Bertalanffy, 1938). Other commonly used alternatives are the generalized VBGM (Pauly, 1979), the Gompertz growth model (Gompertz, 1825), the logistic model (Ricker, 1975), and the Schnute-Richards model (Schnute \& Richards, 1990). The Schnute model (1981) presents a versatile growth model with statistically stable parameters, which includes numerous historical models as special submodels.

Multimodel selection (MMS) based on information theory is a relatively new paradigm in biological sciences and is entirely different from the usual methods based on null hypothesis testing (Katsanevakis, 2006). Modeling growth with an MMS approach requires fitting data to a set of candidate models and selecting the best model based on any information criterion, such as the Akaike (AIC), Bayesian (BIC) or Hannan-Quinn (HQC) (Burnham \& Anderson, 2002).

The VBGM has been used a priori to fit data growth of $O$. libertate from the central Gulf of California and the occidental coast of Baja California Peninsula (Gallardo-Cabello et al., 1993; Carmona \& Alexandres, 1994) and was selected as best model in an MMS approach for data from the southern Gulf of California (Ruiz-Domínguez \& Quiñonez-Velázquez, 2018).

The AIC performance to select the best model is conditioned to have a well-founded set of candidate models and a large enough sample size about the number of parameters (Burnham \& Anderson, 2002). The generalized growth Schnute model includes many other historical growth models so that using it increases the probability of including the real model in the MMS approach. A bias-corrected form of AIC, referred to as AICc (Akaike, 1981; Hurvich \& Tsai, 1989; Shono, 2000; Burnham \& Anderson, 2002), is used to lead with small sample size. Burnham \& Anderson (2002) suggested using AICc if the ratio sample size/parameter number of model $<40$ or always using AICc.

This study analyzes the environmental effect of El Niño, La Niña and Neutral condition on the individual growth of the thread herring $O$. libertate, using an information theory approach to select the best individual growth model of the thread herring; we believe that environmental condition affects model and growth parameters.

\section{MATERIALS AND METHODS}

Samples of thread herring were collected from landings of a small pelagic fleet that operates from Punta Ahome, Sinaloa, to Bahía Banderas, Jalisco $\left(20-27^{\circ} \mathrm{N}\right.$, $\left.105-110^{\circ} \mathrm{W}\right)$. A $12 \mathrm{~kg}$ sample was selected each month, and collected organisms were grouped in $5 \mathrm{~mm}$ intervals of standard length (SL). Then, 10 Opisthonema libertate individuals were randomly selected from each interval, and sagittal otoliths were extracted. Taxonomic identification procedures followed Berry \& Barret's (1963) methodology. The dataset was generated from 2005, 2008 and 2015 because they represent Neutral, La Niña and El Niño conditions, respectively, according to Climate Data Guide (2018).

Otoliths were immersed in pure water for five minutes before digitalization under Carl Zeiss stereoscopic microscope (Stemi 508) with an Axioncam ERc $5 \mathrm{~s}$ camera. Opaque and translucent bands were counted, and opaque band formation periodicity was determined through monthly variation of otolith percentages with this band type based on the contour.

The precision of age determinations from otoliths was evaluated with an average percentage error (APE) according to Beamish \& Fournier (1981) and coefficients of variation (CV) (Chang, 1982).

$$
\mathrm{APE}=100 \times \frac{1}{\mathrm{n}} C V=\frac{1}{n} \sum_{j=1}^{n} \frac{\sqrt{\frac{1}{\mathrm{R}} \sum_{\mathrm{i}=1}^{\mathrm{R}} \frac{(\mathrm{Xij}-\mathrm{Xj})^{2}}{R-1}}}{\mathrm{Xj}} \times 100
$$

where $\mathrm{n}$ fish are aged; $\mathrm{R}$ is the number of times each is aged; let $X_{\mathrm{ij}}$ be the $i$-th age determination of the $j$-th fish, and $\mathrm{X}_{\mathrm{j}}$ is the average age calculate for the $j$-th fish.

We used size at age data and an MMS approach for selecting the best model from five submodels of the Schnute growth model (Burnham \& Anderson, 2002) for $O$. libertate in each environmental condition.

Submodel $1, \mathrm{a} \neq 0$ and $\mathrm{b} \neq 0 Y(t)=\left[\mathrm{Y}_{1}^{\mathrm{b}}+\left(\mathrm{Y}_{2}^{\mathrm{b}}-\mathrm{Y}_{1}^{\mathrm{b}}\right) \frac{1-\mathrm{e}^{-\alpha\left(\mathrm{t}-\tau_{1}\right)}}{1-\mathrm{e}^{-\alpha\left(\tau_{2}-\tau_{1}\right)}}\right]^{\frac{1}{b}}$

Submodel $2, a \neq$ and $b=0 Y(t)=Y_{1} \exp \left[\log \left(\frac{Y_{2}}{Y_{1}}\right) \frac{1-e^{-\alpha\left(t-\tau_{1}\right)}}{1-e^{-\alpha\left(\tau_{2}-\tau_{1}\right)}}\right]$

Submodel 3, $\mathrm{a}=0$ and $\mathrm{b} \neq 0 Y(t)=\left[\mathrm{Y}_{1}^{\mathrm{b}}+\left(\mathrm{Y}_{2}^{\mathrm{b}}-\mathrm{Y}_{1}^{\mathrm{b}}\right) \frac{\mathrm{t}-\tau_{1}}{\tau_{2}-\tau_{1}}\right]^{\frac{1}{b}}$

Submodel $4, a=0$ and $b=0 Y(t)=Y_{1} \exp \left[\log \left(\frac{Y_{2}}{Y_{1}}\right) \frac{t-\tau_{1}}{\tau_{2}-\tau_{1}}\right]$

Submodel 5, a $>0$ and $b=1 \mathrm{Y}(\mathrm{t})=\left[\mathrm{Y}_{1}+\left(\mathrm{Y}_{2}-\mathrm{Y}_{1}\right) \frac{1-\mathrm{e}^{-\alpha\left(\mathrm{t}-\tau_{1}\right)}}{1-\mathrm{e}^{-\alpha\left(\tau_{2}-\tau_{1}\right)}}\right]$

where $\mathrm{Y}(\mathrm{t})$ is the size in age $t, \tau_{1}$ first specified age, $\tau_{2}$ second specified age, $Y_{1}$ size at age $\tau_{1}$ and $Y_{2}$ size at age $\tau_{2}, \alpha$ constant relative rate of relative growth rate, $\mathrm{b}$ incremental relative rate of relative growth rate. Submodel 5 is the same as VBGM (Schnute, 2002). 
We estimated the parameters of each Schnute model submodel by maximizing the log-likelihood function (Hilborn \& Mangel, 1997) with the Newton algorithm (Neter et al., 1996).

$$
\mathrm{LL}=\left(-\frac{\mathrm{n}}{2}\right) \times(\ln (2 \pi)+2 \times \ln (\sigma)+1)
$$

where LL is log-likelihood; $n$ sample size; $\sigma$ standard deviation and was estimated considering distribution normal of error with:

$$
\sigma=\sqrt{\frac{\sum_{\mathrm{i}=1}^{\mathrm{n}}\left(\mathrm{Yt}_{\mathrm{i}}-\widehat{\mathrm{Y}} \mathrm{t}_{\mathrm{i}}\right)^{2}}{\mathrm{n}}}
$$

where $Y_{t i}$ standard length observed, $\hat{Y}_{t i}$ standard length estimated.

The interval confident (IC) was estimated using the log-likelihood profile (Hilborn \& Mangle, 1997).

The best model was selected as that with the minor corrected Akaike information criterion (Akaike, 1981; Burnham \& Anderson, 2002).

$$
A I C=-2 L L+2 K \text { and } A I C_{c}=A I C+\frac{2 k(k+1)}{n-k-1}
$$

Growth curves were contrasted using a Kimura test (Kimura, 1980), but as differences in the number of age groups were observed over the three years compared, further growth curves were contrasted considering only the 0.5 - to 4.5 -year age groups in all three years.

$$
K=-\mathrm{n} \times \ln \frac{R S S_{\Omega}}{R S S_{\omega}}
$$

where $\mathrm{n}$ is the total number of observations from all curves combined, $\operatorname{RSS} \Omega$ is the total sum of squared residuals derived from fitting all curves separately, and $\mathrm{RSS} w$ is the total sum of squared residuals obtained from fitting all data of three years as one curve alone.

For contextualizing environmental conditions in the three years selected for growth analysis of thread herring, we generated stress wind from data of 2002 to 2016 of wind velocity at Mazatlan Airport [https:// www.tutiempo.net/clima/mexico.html] and monthly area-average concentrations of Chl- $a$ [https://giovanni. gsfc.nasa.gov] of sites where pelagic fleets operate.

\section{RESULTS}

A total of 573 otoliths were digitalized as representatives of the three different environmental conditions: Neutral (219 otoliths), La Niña (205 otoliths), and El Niño (149 otoliths) events.

The linear relationship between otoliths radius (RO) and standard length (SL) of Opisthonema libertate was statistically significant $(r=0.907, P<0.05)$, with a determination coefficient of 0.822 , validating this bone structure for age readings (Fig. 1).

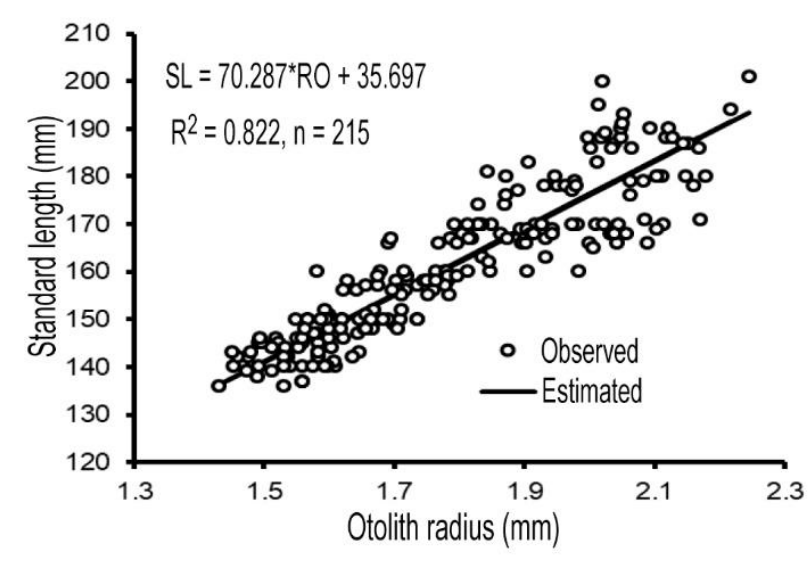

Figure 1. Relationship of otolith radius (RO) versus the standard length (SL) of Opisthonema libertate.

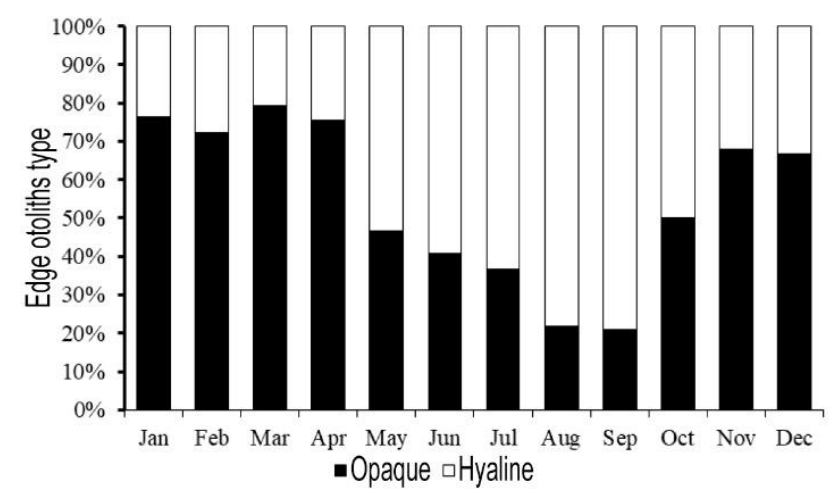

Figure 2. Monthly percentage of type edge otolith of Opisthonema libertate.

Monthly variation of the relative frequency of otolith edge type shows an annual cycle, with the opaque zone dominating through the winter season and the hyaline zone in summer, with a maximum in August-September (Fig. 2). Aging precision was 4.8\% according to APE and $6.1 \%$ with $\mathrm{CV}$. Six age groups were identified in the El Niño and La Niña years, but only five groups in the Neutral year.

The age group of $1+$ years old was dominant in all three environmental conditions, especially in Neutral conditions, but 4+ years old and 5+ years old age groups were less represented (Fig. 3).

The age structure of fish in La Niña and El Niño events were not different statistically $(\mathrm{Z}=0.74, P$ > $0.05)$, and both were different of Neutral condition (Neutral-El Niño; $Z=1.95, P<0.05$ ) and Neutral-La Niña; $Z=2.21, P<0.05$ ) (Fig. 3 ).

The results of multimodel selection analysis are reported in Table 1. Schnute growth model submodel 1 was the better for describing data growth of all three environmental conditions as this submodel experienced minor AICc between candidate models. WAICc were 


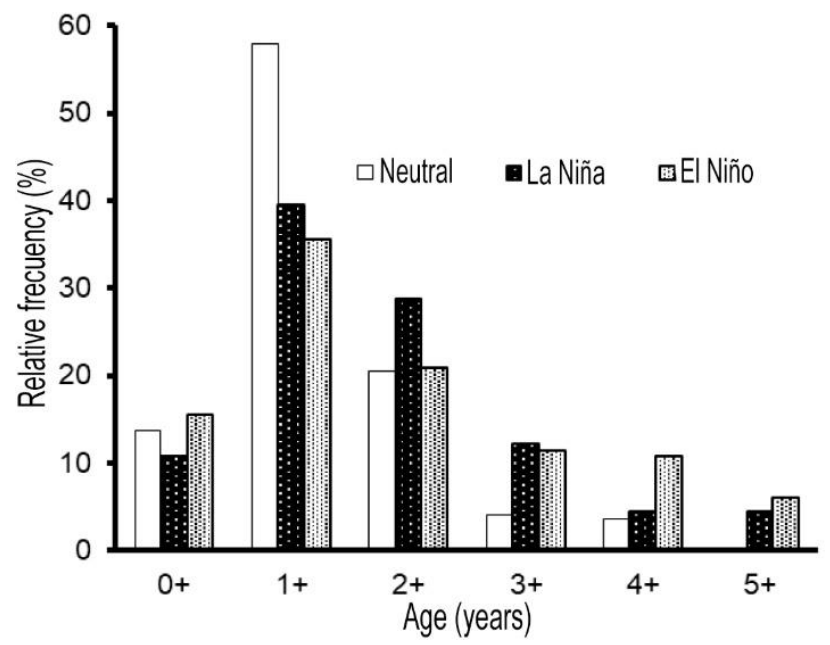

Figure 3. Relative frequency of growth mark otoliths of Opisthonema libertate.

higher than $90 \%$ in El Niño and La Niña conditions, indicating a "clear winner model," but $74.8 \%$ in Neutral condition. For this last condition, submodels 2 and 5 had some support on data. The VBGM represented in this paper for the Schnute model submodel 5, was ranked third in all three environmental conditions with a WAICc of $7.5 \%$ in Neutral conditions and less than $1 \%$ in other two environmental conditions (Table 1). The Schnute model submodel 3 was the best model for data pooled.

Data on the size at the age of each environmental year are shown in Figure 4. In general, a variance decreasing with age was observed in all three years. Comparisons of growth curves among environmental conditions, when all age groups were considered, showed that growth curve in the El Niño event was different to the growth curves in both the La Niña and Neutral conditions $\left(X^{2}=13.2, P<0.05 ; X^{2}=15.4, P<\right.$ 0.05 , respectively). Nevertheless, when only 0.5 - to 4.5-year-old age groups where considered, all three environmental conditions and any combinations were statistically different (El Niño-Neutral $X^{2}=13.8, P<$ 0.05 ; La Niña-Neutral $X^{2}=10.3, P<0.05$ and El NiñoLa Niña $X^{2}=11.9, P<0.05$ ). The 0.5 -year-old age group had a smaller size but a wider range in growth data during El Niño than under other environmental conditions (Fig. 4).

The annual averages of Chl- $a$ concentrations in the fishing zone of $O$. libertate show an increasing trend from 2002 to 2011 and then a decline from 2012 to 2016. The trend of Chl- $a$ is consistent with a slow wind stress period, and its declining trend started with a sharp increase in wind stress in 2012, which persisted to 2015 (Fig. 5).
Years selected as Neutral and La Niña environmental conditions in 2005 and 2008, occurred during high Chl- $a$ concentrations period, with 2 and $3 \mathrm{mg} \mathrm{C} \mathrm{m}^{-3}$ respectively, whereas in El Niño environmental conditions, Chl- $a$ concentrations were less than $2 \mathrm{mg} \mathrm{C} \mathrm{m}^{-3}$.

\section{DISCUSSION}

A monthly variation on the relative frequency of otoliths edge type of Opisthonema libertate suggests an annual formation of growth annulus. The time of the otolith opaque zone formation matches the seasonal maximum Chl- $a$ concentration, which occurs during winter and spring on the Sinaloa and Nayarit coast (Cepeda-Morales et al., 2017), which operates a small pelagic fleet. High Chl- $a$ concentrations mean high food availability for small pelagic fishes that feed on phytoplankton or small zooplankton (Jacob-Cervantes et al., 1992) and support a period of highest growth. Hyaline zone formation is consistent with the summer reproduction season (Nevarez et al., 2006), indicating a slow growth as more energy is dedicated to the growth of gonadal maturity for reproduction. The first hyaline zone forms during the first year of life because a mature $O$. libertate is reported to reach a size of $135 \mathrm{~mm} \mathrm{SL}$ (130, 139; IC95\%) (Jacob-Cervantes \& AguirreVillaseñor, 2014) and average size at first hyaline zone estimated in this study is between 143 and $145 \mathrm{~mm}$ SL. A related clupeid, $O$. oglinum, reaches a size of $145 \mathrm{~mm}$ SL in its first year of life (Smith, 1994).

Although there are no reference points for aging precision for fishes, values of both precision indexes $(\mathrm{APE}=4.8 \%, \mathrm{CV}=6.1 \%)$ used here were close to the median of 117 age studies of fishes (APE $=5.5 \%, \mathrm{CV}$ $=7.6 \%$ ) and were recommended as a maximum limit reference (Campana, 2001).

The Schnute model, submodel 1, was selected as the best in all three environmental conditions. However, in La Niña and El Niño environmental conditions, submodel 1 was as a clear winner (WAIC > 90\%), whereas in Neutral environmental conditions, no was a clear winner (WAIC $=72.3 \%$ ), as the data also supported submodel 2 and VBGM (WAIC $=15$ and $10 \%$, respectively). VBGM, which has been selected $a$ priori in previous studies (Gallardo-Cabello et al., 1993; Carmona \& Alexandres, 1994), was ranked third among candidate models with a $\Delta$ AIC $>7$ in La Niña and El Niño but 3.8 in Neutral environmental conditions. As observed in this study, VBGM did not fit the growth of this species adequately, and similar results were reported by Katsanevakis \& Maravelias 
Table 1. Growth model parameters, AICc, and WAICc for each environmental condition. *Better model.

\begin{tabular}{lccccccrr}
\hline Condition & Submodel & $\mathrm{y}_{1}$ & $\mathrm{y}_{2}$ & $\mathrm{a}$ & $\mathrm{b}$ & $\mathrm{AICc}$ & $\Delta$ AICc & WAICc \\
\hline Neutral & 1 & 136.554 & 186.345 & 0.905 & -7.686 & $\mathbf{1 0 9 2 . 4}$ & 0 & 74.8 \\
& 2 & 136.166 & 187.346 & 0.237 & 0 & 1095.5 & 3.1 & 15.9 \\
& 3 & 136.160 & 187.984 & 0 & 2.670 & 1099.9 & 7.5 & 1.8 \\
& 4 & 139.098 & 193.210 & 0 & 0 & 1170.2 & 77.9 & 0.0 \\
& 5 & 136.132 & 187.506 & 0.150 & 1 & 1097.0 & 4.6 & 7.5 \\
\hline La Niña & 1 & 137.848 & 187.985 & 0.894 & -7.973 & $\mathbf{1 0 0 4 . 6 *}$ & 0 & 95.9 \\
& 2 & 137.019 & 189.856 & 0.299 & 0 & 1011.5 & 6.8 & 3.2 \\
& 3 & 136.814 & 191.234 & 0 & 3.998 & 1023.0 & 18.3 & 0 \\
& 4 & 142.390 & 198.653 & 0 & 0 & 1166.3 & 161.7 & 0 \\
\hline El Niño & 5 & 136.924 & 190.120 & 0.226 & 1 & 1013.9 & 9.3 & 0.9 \\
& 1 & 125.480 & 198.126 & -0.490 & 10.373 & $\mathbf{8 6 6 . 4}$ & 0 & 98.8 \\
& 2 & 127.782 & 195.336 & 0.428 & 0 & 901.0 & 34.7 & 0 \\
& 3 & 126.088 & 196.248 & 0 & 4.834 & 875.2 & 8.9 & 1.2 \\
& 4 & 136.563 & 204.585 & 0 & 0 & 1035.4 & 169 & 0 \\
\hline Pooled data & 5 & 127.431 & 195.587 & 0.335 & 1 & 895.0 & 28.6 & 0 \\
& 1 & 133.164 & 195.035 & -0.071 & 4.807 & 3229.4 & 1.7 & 29.5 \\
& 2 & 133.913 & 193.642 & 0.317 & 0 & 3238.3 & 10.6 & 0.3 \\
& 3 & 133.262 & 194.735 & 0 & 3.939 & $\mathbf{3 2 2 7 . 7}$ & 0 & 67.6 \\
& 4 & 139.706 & 203.428 & 0 & 0 & 3565.4 & 337.6 & 0 \\
& 5 & 133.739 & 193.920 & 0.236 & 1 & 3234.3 & 6.6 & 2.5 \\
\hline
\end{tabular}
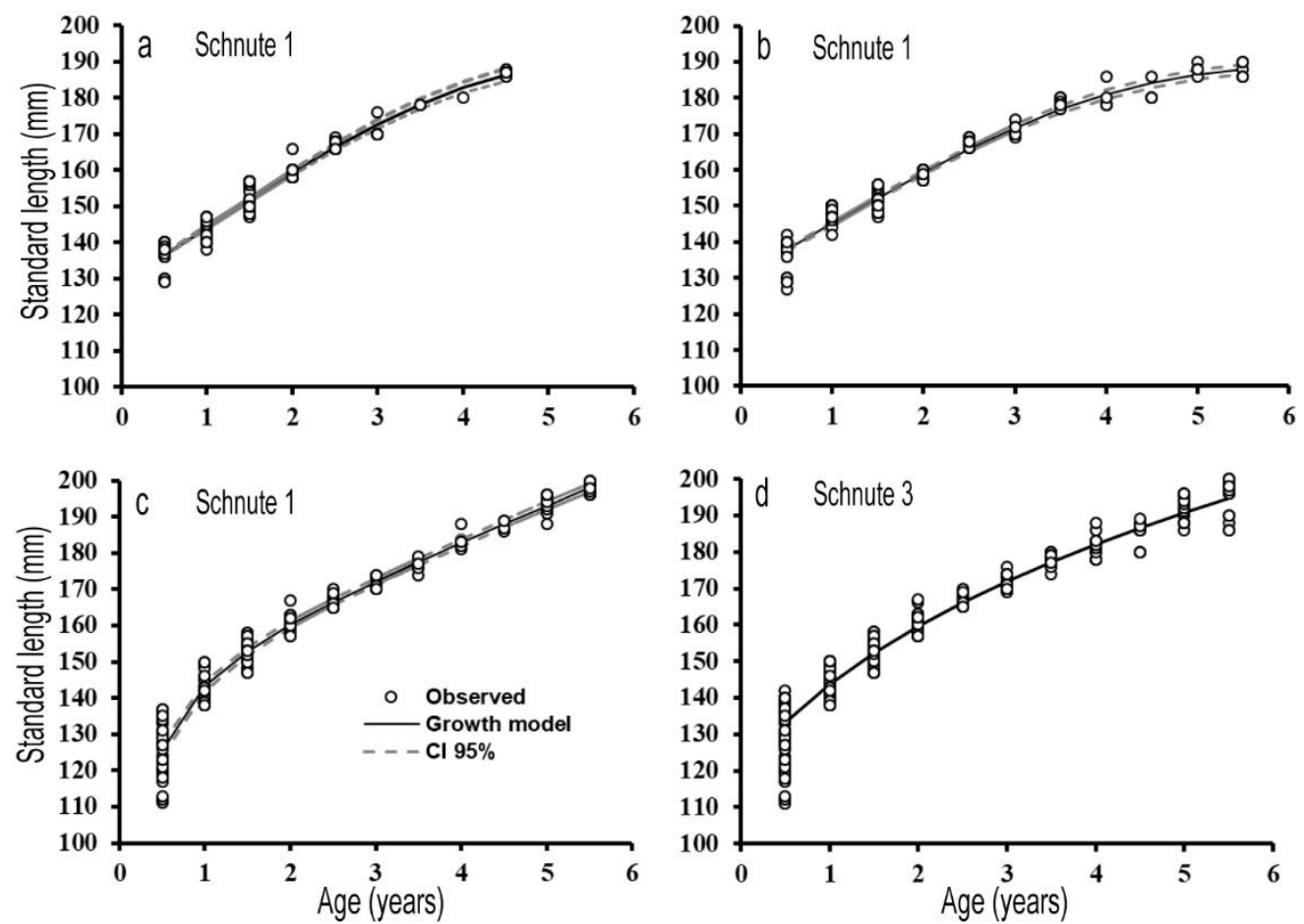

Figure 4. Growth curves of Opisthonema libertate for a) Neutral, b) La Niña, c) El Niño, and d) pooled data.

(2008), who found that VBGM was not the best model for 87 of 133 fish species.
Parameters of the best submodel selected in Normal and La Niña condition were $a>0$ and $b<0$ and are equivalent to Richards growth model (Schnute, 1981), 


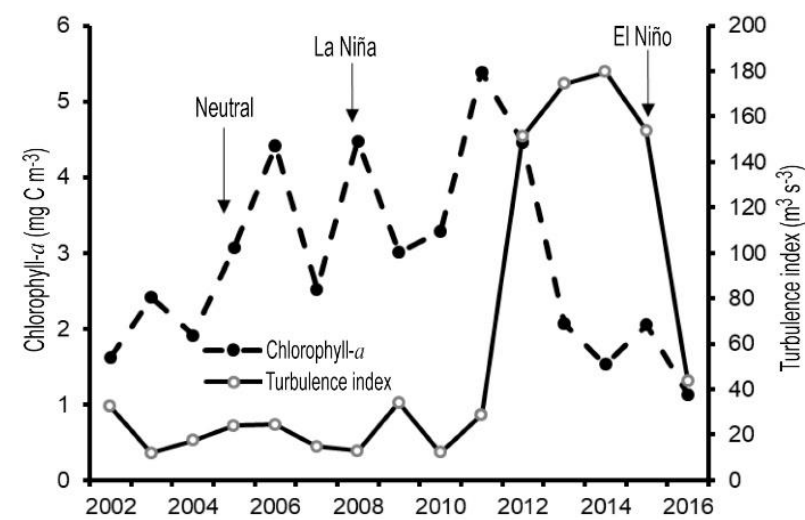

Figure 5. The trend of environmental conditions in the southern Gulf of California.

but that in "El Niño" condition where $a<0$ and $b>0$, has not any historical growth model equivalent. In pooled data, parameters of the best model selected were $\mathrm{a}=0$ and $\mathrm{b}>1$ and also have not any historical growth model equivalent. Parameters $a$ and $b$ of that last both growth curves lie region three in the a-b plane of Schnute (1981). The growth curve is not asymtotic but becomes unbounded. This growth curve represents accelerated growth in last sizes, but when $a=0$ represents an unbounded decelerated growth. Ages 4 and older accelerated growth in El Niño condition relative to the other ones analyzed. This accelerated growth in the El Niño year could be a sample size effect, as explained later.

The main variation in length for the 0.5- and 1.0year-old age groups is due to different environmental conditions during the birth year and after the first year of life. The variance decrease in length for the 2-yearold age group and older are growth compensation. The growth of herring in the first year could be restricted for both food scarcity during El Niño events and intraspecific competition, with dominant fish species growing more than subordinate ones. When food availability rises or competition alleviates due to the end of life mortality, subordinates fish species to experience growth compensation; as the animals grow older, in this submodel, the small ones tend to catch up analogous to children approaching adulthood (Schnute \& Fournier, 1980). Compensatory growth has been reported for marine fish species (Ali et al., 2003) as well as reared fish and shrimp such as rainbow trout Oncorhynchus mykiss and white shrimp Penaeus vannamei (Dobson \& Holmes, 1984; Aragón-Noriega et al., 2017).

The growth curve of El Niño was different from the Neutral and La Niña growth curves $\left(X^{2}=13.2, P<0.05\right.$; $X^{2}=15.4, P<0.05$, respectively) when all the otolith readings for each environmental condition were used. Differences between growth curves of $O$. libertate in the three environmental conditions evaluated are fixed for the first (0.5-year-old) and last (5.0 and 5.5-yearold) age groups. The size of the 0.5 -year-old age group in fish during El Niño conditions were smaller than all other conditions. The minor size in this age group, born during El Niño, concerning other environmental conditions, might be associated with a slow growth rate, because of food scarcity for early-stage $O$. libertate in El Niño conditions. Low Chl- $a$ concentrations and primary productivity are common during El Niño events in the southern Gulf of California (Escalante et al., 2013). Possible downstream effects of weak primary production on secondary production and food for $O$. libertate could be responsible for the small size of the 0.5-year-old age group born during an El Niño event.

A stable ocean environment is necessary for high Chl- $a$ and low zooplankton concentrations (Lasker $e t$ al., 1970; Lasker \& Zweifel, 1978) for meeting the nutrition demand of the 0.5 -year-old age group $O$. libertate. Wind stress in the $2015 \mathrm{El}$ Niño event was five times higher than wind stress during both the 2008 La Niña and 2005 Neutral conditions. Strong wind speed in 2015 may have produced instability in the water column, low Chl- $a$, and widespread food scarcity for the 0.5-year-old age group of $O$. libertate, which in turn affects growth rate.

Differences in the size of the 5- and 5.5-year-old age groups $O$. libertate between the three different environmental conditions scenarios could be more a sample size effect because these ages are not largely represented in the collected samples.

After the 0.5-year-old age group, all three-growth curves are coincident, which supports a compensatory effect. After a bad year, once better environmental conditions are reestablished, small herrings grow faster and reach the same size and weight as those born in better environmental conditions.

As compensatory growth smooth differences on growth rate among young herrings born in different environmental conditions, the best approximation to model growth of $O$. libertate could be that of pooled data in years with different environmental conditions. Schnute model submodel 3 was the best selected on pooled data in this study and submodel 1 was the best in each environmental condition year and second in pooled data with a WAIC $=29.5 \%$, the multimodel inference approach, with an average of the Schnute model submodels 1 and 3 could be used.

\section{ACKNOWLEDGMENTS}

We thank the staff of Maz Sardina S.A. of C.V. by the thread herring samples, to the Small Pelagic Program 
of the Regional Fisheries Research Center of Mazatlán of INAPESCA-SAGARPA, by the access to data and biological materials, to Dr. Felipe Amezcua of the Institute of Marine Sciences and Limnology (ICMyL, UNAM), who allowed equipment for otolith images digitalization. To the National Council of Science and Technology (CONACyT) for the grant awarded for postgraduate studies.

\section{REFERENCES}

Akaike, H. 1981. Likelihood of a model and information criteria. Journal of Economics, 16: 3-14.

Aragón-Noriega, E.A., Mendivil-Mendoza, J.E., Valenzuela-Quiñónez, W. \& Félix-Ortiz, J.A. 2017. Multi-criteria approach to estimate the growth curve in the marine shrimp, Penaeus vannamei Boone, 1931 (decapoda, penaeidae). Crustaceana, 90(11-12): 15171531.

Berry, D.H. \& Barret, I. 1963. Gillraker analysis and speciation in the thread herring genus Opisthonema. Bulletin of Inter-American Tropical Tuna Commission, 7(2): 137-190.

Beamish, R.J. \& Fournier, D.A. 1981. A method for comparing the precision of a set of age determinations. Canadian Journal of Fisheries and Aquatic Sciences, 38: 982-983.

Beckman, D.W. \& Howlett, D.T. 2013. Otolith annulus formation and growth of two redhorse suckers (Moxostoma: Catastomidae). Copeia, 2013(3): 390395.

Beninger, P.G., Boldina, I. \& Katsanevakis, S. 2012. Strengthening statistical usage in marine ecology. Journal of Experimental Marine Biology and Ecology, 426-427: 97-108.

Burnham, K.P., \& Anderson, D.R. 2002. Model selection and multimodel inference: a practical informationtheoretic approach. Springer, New York.

Campana, S.E. 2001. Accuracy, precision and quality control in age determination, including a review of the use and abuse of age validation methods. Journal of Fish Biology, 59: 197-242.

Carmona, R. \& Alexandres, F. 1994. Determinación del crecimiento de Opisthonema libertate (Clupeiformes: Clupeidae) mediante lecturas de otolitos. Revista de Biología Tropical, 42(1-2): 233-238.

Cepeda-Morales, J.F., Hernández-Vázquez, J., RiveraCaicedo, C., Romero-Bañuelos, E., Inda-Díaz, E. \& Hernández-Almeida, O. 2017. Seasonal variability of satellite derived chlorophyll and sea surface temperature on the continental shelf of Nayarit, Mexico. Revista Bio Ciencias, 4(6): 1-17.

Cisneros-Mata, M.A., Montemayor-López, G. \& Nevárez-Martínez, M.O. 1996. Modeling determi- nistic effects of age structure, density dependence, environmental forcing and fishing on the population's dynamics of Sardinops sagax caeruleus in the Gulf of California. California Cooperative Oceanic Fisheries Investigations Report, 37: 201-208.

Climate Data Guide. 2018. The Climate Data Guide: Nino SST indices (Nino 1+2, 3, 3.4, 4; ONI and TNI). [https://climatedataguide.ucar.edu/climate-data/ninosst-indices-nino-12-3-34-4-oni-and-tni]. Reviewed: September 5, 2018.

Durazo, R., Gaxiola-Castro, G., Lavaniegos, B., CastroValdez, R., Gómez-Valdés, J. \& Mascarenhas, A. 2005. Oceanographic conditions west of the Baja California coast, 2002-2003: a weak El Niño and subarctic water enhancement. Ciencias Marinas, 31(3): 537-552.

Escalante, F., Valdez-Holguín, J.E., Álvarez-Borrego, S. \& Lara-Lara, J.R. 2013. Temporal and spatial variation of sea surface temperature, chlorophyll $a$, and primary productivity in the Gulf of California. Ciencias Marinas, 39(2): 203-215.

Espinoza-Carreón, T. \& Valdez-Holguín, J.E. 2013. Gulf of California interanual chlorophyll variability. Ecological Applications, 6(1-2): 83-92.

Gallardo-Cabello, M., Laguarda-Figueras, A. \& CorralesUrrea, R. 1993. Análisis de la edad, crecimiento y mortalidad de la sardina crinuda Opisthonema libertate (Gunther, 1868) de las aguas del sur del Golfo de California. Ciencia Pesquera, 9: 137-146.

Gompertz, B. 1825. On the nature of the function expressive of the law of human mortality, and on a new mode of determining the value of life contingencies. Philosophical Transactions of the Royal Society B: Biological Sciences, 115: 513-538.

Hilborn, R. \& Mangel, M. 1997. The ecological detective. Confronting models with data. Princeton, New Jersey.

Hurvich, C.M. \& Tsai, C.L. 1989. Regression and time series model selection in small samples. Biometrika, 76: 297-307.

Jacob-Cervantes, M.L. 2010. La pesquería de peces pelágicos menores en el sur del Golfo de California. Análisis de la temporada de pesca 2008. Ciencia Pesquera, 18: 47-58.

Jacob-Cervantes, M.L. \& Aguirre-Villaseñor, H. 2014. Inferencia multimodelo y selección de modelos aplicados a la determinación de L50 para la sardina crinuda Opisthonema libertate del sur del Golfo de California. Ciencia Pesquera, 22(1): 61-68.

Jacob-Cervantes, M.L., Gallardo-Cabello, M., ChiapaCarrara, X. \& Ruiz-Luna, A. 1992. Régimen alimentario de la sardina crinuda Opisthonema libertate (Pisces: Clupeidae) en el Golfo de California. Revista de Biología Tropical, 40(2): 233-238. 
Katsanevakis, S. 2006. Modelling fish growth: model selection, multimodel inference, and model selection uncertainty. Fisheries Research, 81: 229-235.

Katsanevakis, S. \& Maravelias, C.D. 2008. Modelling fish growth: multi-model inference as a better alternative to a priori using the von Bertalanffy equation. Fish and Fisheries, 9: 178-187.

Kimura, D.K. 1980. Likelihood methods for the von Bertalanffy growth curve. Fishery Bulletin, 77: 765776.

Lasker, R. \& Zweifel, J.R. 1978. Growth and survival of first feeding northern anchovy Engraulis mordax in patches containing different proportions of large and small prey. In: Steele, J.H. (Ed.). Spatial pattern in plankton communities. Plenum Press, New York, pp. 329-354.

Lasker, R., Feder, H.M., Theilacker, G.H. \& May, R.C. 1970. Feeding, growth, and survival of Engraulis mordax larval reared in laboratory. Marine Biology, 5: 345-353.

Lanz, E., Nevárez-Martínez, M.O., López-Martínez, J. \& Dworak, J.A. 2009. Small pelagic fish catch in the Gulf of California associated with sea surface temperature and chlorophyll. California Cooperative Oceanic Fisheries Investigations Report, 50: 134-146.

Lluch-Belda, D., Magallón, B.F.J. \& Schwartzlose, R.A. 1986. Large fluctuations in the sardine fishery in the Gulf of California: possible causes. California Cooperative Oceanic Fisheries Investigations Report, 27: $136-140$.

Neter, J., Kutner, M.H., Nachtsheim, C.J. \& Wasserman, W. 1996. Applied linear statistical model. McGrawHill, New York.

Nevárez-Martínez, M.O., Martínez-Zavala, M.A., CoteroAltamirano, C.E., Jacob-Cervantes, M.L., Green-Ruiz, Y.A., Gluyas-Millán, G., Cota-Villavicencio, A. \& Santos Molina, J.P. 2006. Peces pelágicos menores. In: Arreguín-Sánchez, F., Beléndez-Moreno, L., MéndezGómez, L., Solana-Sansores, R. \& Rangel-Dávalos, C. (Eds.). Sustentabilidad y pesca responsable: evaluación y manejo. Instituto Nacional de la Pesca, México D.F., pp. 265-301.

Received: 25 March 2019; Accepted: 4 July 2019
Ricker, W.E. 1975. Computation and interpretation of biological statistics of fish populations. Bulletin of the Fisheries Research Board of Canada. The Blackburn Press, New Jersey.

Ruiz, L.A. \& Lyle, F.L. 1992. Fluctuaciones periódicas de la captura de sardina crinuda (Opisthonema spp.) en el Golfo de California, 1972-1990. California Cooperative Oceanic Fisheries Investigations Report, 33: 124-129.

Ruiz-Domínguez, M. \& Quiñonez-Velázquez, C. 2018. Edad, crecimiento y mortalidad de Opisthonema libertate en las costas del noroeste de México. Ciencias Marinas, 44(4): 235-250.

Schnute, J. \& Fournier, D. 1980. A new approach to length-frequency analysis: growth structure. Canadian Journal Fisheries and Aquatic Sciences, 37: 13371351.

Schnute, J. 1981. A versatile growth model with statistically stable parameters. California Cooperative Oceanic Fisheries Investigations Report, 38: 11281140.

Schnute, J.T. \& Richards, L.J. 1990. A unified approach to the analysis of fish growth, maturity, and survivorship data. Canadian Journal of Fisheries and Aquatic Sciences, 47: 24-40.

Shono, H. 2000. Efficiency of the finite correction of Akaike's information criteria. Fisheries Science, 66: 608-610.

Smith, J.W. 1994. Biology and fishery for Atlantic thread herring Opisthonema oglinum, along the North Carolina Coast. Marine Fisheries Review, 56: 1-7.

Von Bertalanffy, L. 1938. A quantitative theory of organic growth. Human Biology, 10: 181-213. 